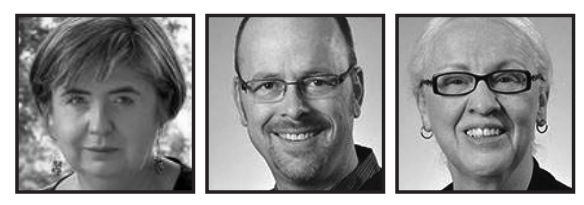

\title{
The Ed.D. as Investment in Professional Development: Cultivating Practitioner Knowledge
}

\author{
Margaret Macintyre Latta, University of British Columbia Okanagan \\ Edmund T. Hamann, University of Nebraska-Lincoln \\ Susan A. Wunder, University of Nebraska-Lincoln
}

\begin{abstract}
As teacher educators and participants in the US-based Carnegie Project for the Education Doctorate (CPED) initiative to differentiate the Ed.D/Ph.D., we have programmatic commitments to the centrality of practitioner knowledge for shaping professional development. Through CPED, we structure opportunities for local educators to develop their professional practices within their graduate studies toward an Ed.D, while maintaining full-time educational work commitments. Concurrently, we examine and document how CPED creates room, alongside concrete practice, to cultivate, promote, and value the voices, sensibilities, and capacities of practitioners engaged in advanced practices. In doing so, we confront marginalization of practitioners' perspectives in the field and seek conditions and supports that insist on educators' primary role in the complex project of education worldwide.
\end{abstract}

"[F]or the good of ourselves and our students, I believe that teachers must become part of the research conversations and policy creation surrounding education. Teacher research makes what we do, why we do it, and how it works visible and justifies it to ourselves and to others. It provides specific and situated cases. Without teacher voices, grounded in experience and clear-eyed interpretations of the data in our classrooms, policies will not be fully informed, and implementations will be inefficient." (Wilhelm, 2008, p. 55) 


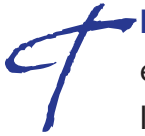

his account challenges persistent worldwide views in the field of education that conceive of practitioner knowledge through deficit lenses (see overview in Townsend \& Bates, 2007). The impoverished de-professionalization concerning teaching and teacher education that results from such deficit lenses trivializes associated views of what teaching entails and the applicability of educators' lived understandings to their own practice. These matters trouble us and have brought us together for more than five years, collaborating on a practitioner-centric Education Doctorate (Ed.D.) program.

Shulman (2004) has drawn attention to the hazards of dismissing/overlooking practitioner knowledge. In his words, "The currently incomplete and trivial definitions of teaching held by the policy community comprise a far greater danger to good education than does a more serious attempt to formulate the knowledge base" (p. 243). Written over a decade ago when Shulman also helped found the national Carnegie Project on the Education Doctorate (CPED), his words are even more urgent now. CPED, which has supported many campuses in the United States in differentiating the Ed.D. and the Ph.D., operates as a counter-narrative to the larger trajectory that Shulman decries. In turn, CPED has afforded us as participants in this project an opportunity to collaborate on efforts to affirm and grow educators' practitioner knowledge.

Although varying by site, CPED prompts participants to structure meaningful opportunities for educators to develop their professional practice within the course of their Ed.D. studies while maintaining full-time teaching and/or related commitments. Through examining the concrete experiences of our own institutional efforts as colleagues in the same department from 2005 to 2012, we reflect on how this initiative positioned us and our Ed.D. students to cultivate and to articulate practitioner knowledge while giving shape to a distinct new program. The shape our Ed.D. program has taken acknowledges the formative nature of professional development and its generative potential for creating rich learning experiences and changed pedagogy for all involved.

To clarify our own roles in relation to both CPED and as coauthors, in the institutional home we shared for eight years, we have been the initiator (Macintyre Latta), program coordinator (Wunder), and three-time teacher (Hamann) of the first course that Ed.D students encounter in our program. We are varyingly and complementarily prepared and professionally oriented in curriculum studies (Macintyre Latta), social studies education (Wunder), and the anthropology of education and educational policy (Hamann). Our arguments are grounded mainly in our experiences (including student feedback) from the initiation of our department's CPED participation in 2007 through 2012. 
CPED offers national commitments that incubate, inform, and protect the more local pathways that we helped co-create on our campus to embed programmatic structures, supports, and resources that prioritize practitioner knowledge. Our story of process documents the search for meaningful opportunities for educators to develop their professional practice within the course of their graduate studies alongside their continuing full-time teaching and other professional commitments. We field-tested course experiences where educators' practices could be developed and nurtured. Such experiences valued interdisciplinarity, multiple methodological perspectives, and interactions and deliberations across participants' interests and content areas. We grappled with programmatic questions such as: What are the principles, pedagogies, and core features that shape our potential Ed.D. graduates' investment in their professional knowledge? We confronted questions concerning graduates' changing identities as they moved through their studies (akin to those shared by Wilhelm [2008]). For example: How might Ed.D. graduates challenge traditional disciplinary and institutional structures, strive for connections between and amongst disciplines, demand continuous engagement in reflection and deliberation, and honor teaching and learning as complex, creative, and developmental in nature? What might be the lived consequences of this posture for teachers, learners, and curriculum in the short and long term?

Our challenge for CPED program design led us to see value in investing in the kind of practitioner knowledge that would allow for the formation of educators entrusted with furthering learning within and from their varied contexts of teaching/ learning experiences. We saw the cultivation of practitioners' professional knowledge as fundamental, given the inherent complexities that educators encounter in P-16 classrooms and community teaching/learning settings. Similarly, we believed that the interchange of knowledge-that is, sustained problem-solving communication between advanced practitioners (Hamann, 2005) - would be generative both for developing new knowledge and reiterating practice as a site of expertise. Our program investment purposefully oriented our version of CPED toward scholars of educational practice, creating the necessary spaces where educators' practices could be developed and nurtured, problems of practice examined as challenges and opportunities, and greater agency claimed by educators for furthering learning (their own, that of their colleagues and professors, and that of their students).

Collectively, 12 faculty members in our Department of Teaching, Learning and Teacher Education envisioned an intellectually rigorous and contextually relevant program of study in which educators would create and sustain effective teaching/ learning contexts that fittingly responded to the concrete realities of P-16 classrooms 
and community educational settings. Our resulting program attracted educators interested in teacher education, professional development, and teacher-leader and advocacy positions in educational venues of all kinds. As a whole, the program conceptualizes the scholarship of teaching as "both substance and process," and as being critical to educators who can "analyze, evaluate, and-most importantmodel and teach practice to future and current active teachers" (Shulman, Golde, Conklin Bueschel, \& Garabedian, 2006, p. 30) in a cross section of educational settings. Our conceptualization has relied on educators to be actively engaged in their professional working environments while concomitantly exploring theories, ideologies, and applications in conversations with peers and faculty. Documenting these efforts to value and grow practitioner knowledge across six years and three doctoral cohorts, intersecting questions continually arise for all involved such as:

- What is entailed in being a professional practitioner?

- What constitutes practitioner knowledge?

- How does practitioner knowledge relate to other forms of educational knowledge?

- Why and how is practitioner knowledge related to policy/practice/research concerns? Does it challenge the privileging of "research" or "policy" perspectives?

- What are the principles, pedagogies, and core features committed to practitioner knowledge that shape our graduate program in teacher education and could shape others?

- Why and how does practitioner knowledge challenge research orthodoxies, and disciplinary and institutional structures?

- What are the implications for education policies, education practices, and the futures envisioned for local communities alongside national and international impacts?

We increasingly see these questions as holding the substance fundamental to both defining and illustrating the value, complexity, and nuance of practitioner knowledge. So we have pursued processes for investing in the kind of practitioner knowledge that continues the formation of educators who can voice and respond to ever-changing teaching/learning contexts (including shifting educational policy milieus) with the necessary insights to promote genuine inquiry-based learning (their own and that of their students and colleagues).

Programmatically, we find that the questions, processes, and commitments shaping the CPED initiative in our institution have asked educators to continually discern what they are doing and why within their professional settings and how they presume to know. In doing so, it reveals to all involved the importance of attending to the formative 
nature of practitioner knowledge from initial teacher education to more advanced inquiry in doctoral studies. Such professional knowledge, entailing both the substance and process of inquiry, serves as the necessary ground for professional development that invests in teachers' voices, sensibilities, and capacities to build, nurture, and sustain worthwhile learning experiences. In turn, we surmise that such ground will instill the experiential conditions that speak back to the impoverished contemporary interpretations dominating many professional development initiatives (see for example, Day, 2000; Easton, 2008; Lieberman \& Pointer-Mace, 2008; Richardson, 2003; Trachtman, 2007). Thus, an inquiry stance (Cochran-Smith \& Lytle, 2009) is at the heart of educator professional development and needs to be modeled and practiced on a continuous basis.

\section{Finding A Way To Proceed}

Borko (2004) notes that the characteristics of design-based research are very fitting for examining educators' professional development and processes. These have permeated our efforts from the first syllabus of the very first course in which our Ed.D. cohort engaged. These efforts attend to the substance and process of our programmatic inquiry into the formative nature of practitioner knowledge from within the conduct of the inquiry itself. Design-based research fittingly aims to improve educational practices through iterative analysis and implementation derived through collaborations across researchers and practitioners fostering contextually sensitive ways to proceed (Wang \& Hannafin, 2005). Design-based research also serves as a guide as we document our institutional efforts to create, implement, and redesign the graduate teacher education program that leads to the Ed.D. In short then, design research describes both our efforts to create, shape, and then reshape a practitioner-oriented Ed.D. program and much of the content with which we engage these practitioner graduate students (so that they can use design research frameworks as they identify, investigate, and then respond to a problem of practice during the program and afterward).

In January 2009, the first cohort enrolled in our program with most earning their doctorates by August 2012. In January 2011, a second cohort matriculated into our Ed.D. program that retained many but not all of its original features. $A$ third cohort matriculated in January 2013 (again encountering adaptations and revisions) and, the cycle continues. Revisions include ways of figuring out how to have earlier cohorts interact with more recent ones, but the core premises of building cohorts and establishing practitioner-affirming habits of interaction have stayed constant. 
Our account is that of conjoint designers, researchers, and reflective teacher practitioners. We are not the students in this program, but we have been and are the advisors of many of them and the professors of more. Participating programmatic CPED faculty meet regularly, operating both as researchers and practitioners designing and redesigning the Ed.D. program guided by five interrelated characteristics of design-based research. First, the issues and considerations that form the substance of our design meetings emphasize the pragmatics of theory/practice relationships on an ongoing basis. We become evermore cognizant of the importance of mutual development and participation by all involved in our programmatic design throughout the process. In this way, the design pragmatically enacts and refines theory/practice relations continuously (Cobb, Confrey, diSessa, Lehrer, \& Schauble, 2003; Edelson, 2002; van den Akker, 1999). Second, the substance of our design meetings is grounded in both theory and the concrete realities of practice (Wang \& Hannafin, 2005). The evolving programmatic context surfaces the complexities, dynamics, and limitations of practice forming the relational intersections that generate and elaborate our theorizing process throughout. Collaboration becomes integral to the cyclical design and redesign nature. So, third, interaction and deliberation are key features of the iterative and flexible structure understood to be always in the making. The recursive movement that ensues within the design process allows for programmatic flexibility. And, participating faculty come to appreciate how time together intentionally moving from analysis-todesign-to-reflection-and-redesign makes visible the programmatic strengths alongside the needed changes, creating room for continual refinement (Bannan-Ritland, 2003; Design-Based Research Collective, 2003). Fourth, the multiple perspectives and involvements of both our faculty team and the Ed.D. students ensure integration of data sources, methods of data collection, and analysis of procedures that are interdependent with the needs of the program. We are thus relationally accountable to each other as the documentation of our efforts reveals a body of evidence that supports the practices and directions taken (Macintyre Latta \& Field, 2005; Carr, 2000; Sidorkin, 2002). And, fifth, context intentionally connects the design process with our findings as the inquiry is conducted; embracing the in situ particularities entailed every step of the way. So, methodologically, our inquiry is also a case study. Our careful programmatic documentation aims to be of service to other institutions' efforts to redesign their doctoral studies in education by offering opportunities for them to examine findings in relation to their own contexts and needs, adapting for their own purposes (Stake, 2005; Yin, 2003).

For programmatic design and revision purposes, as well as to participate in and contribute to national CPED events, we have created policy documents, including recruitment materials, program design materials, syllabi, comprehensive exam 
guidance, and practice-oriented dissertation examples. One data source then for this paper is this evolving textual artifact record of what we have done and per what logics. Yet, an adequate portrayal of this program as enacted, what it really has been vis-à-vis participants' experiences, requires also examining collected accounts from students and faculty. These include representative artifacts of student course work, questionnaire responses from students, electronic discussion boards, published chapters documenting aspects of the program as directly experienced by faculty and students, and minutes from CPED faculty meetings.

Data collection and analysis operate both inductively and deductively throughout, providing means to address the interfaces among the empirical data collected, its interpretations, the research literature, and the design process taking shape. Our search for programmatic experiences that cultivate practitioner knowledge as "both substance and process" positions all involved in this inquiry to do the same. And, it is the concomitant attention toward substance and process that characterizes the unfolding inquiry and our analysis as a whole. Over four cohorts, this inquiry becomes "an ongoing project of configuring description and theory into larger patterns" (Nespor, 2006, p. 298). The ground we encounter is patterned again and again by a growing vocabulary to voice practitioner knowledge, heighten sensibilities toward learners/learning, and enlarge capacities to cultivate the needed circumstances for genuine learning contexts. Attention now turns to these patterns "in ways that maximize opportunities to extend patterns, discover new elements, and multiply connections among elements" (p. 300). Representative CPED student voices/words illustrate these patterns, with permissions in place for all included data.

\section{Cultivating Educators' Voices}

The imposed, top-down, and purportedly research-based education policies that emphasize high stakes testing in education have not improved student achievement, equity, and professional working conditions (Proefriedt, 2008; Ravitch, 2010, 2013). And, yet, practitioners continue to be typically controlled and restricted by such efforts, rather than seen as agentive sources of important insight best positioned to foster improvements at their sites of practice. As we meet our Ed.D. cohort students, what they reveal to us as constituting their practitioner knowledge reflects this tension. Educators endeavor to articulate what is being undermined or lost altogether as they find themselves relaying their teaching practices in limiting ways that under-analyze, decontextualize, and reduce practitioner knowledge to instructional methods and tools disassociated from the particulars of content, students, and situation (Chan, 2012; Heaton \& Swidler, 2012; McGowan \& Pedersen, 2012). For example, a third-cohort Ed.D. 
student, in considering Eisner's (1992) contention that, "if the curriculum is the systole of education, teaching is the diastole. No curriculum teaches itself and how it is mediated is crucial" (p. 624), explained in his second week in the program:

No Child Left Behind (NCLB) is the tool created to make sure that the new curriculum, which was developed as a part of the standards movement, is not only being taught but is being learned by students. The accountability that NCLB is supposed to provide and what it actually produces represents the dichotomy Eisner identified as "the intended curriculum and the operational curriculum." Schools are pressed to improve scores on state mandated tests that are primarily machine scored. Multiple choice test items are ineffective measures of the skills and the abilities that students are going to need to be successful in a globalized, post-high school world...

Our Ed.D. students have a pragmatic, but also skeptical perspective on the U.S. preoccupation with the "what works" education agenda. The quote above represents the dilemma while grappling for an agentive response. Even with this analysis, educators may assume a compliant mode (Groundwater Smith \& Mockler, 2009), although the act of pursuing an Ed.D. may represent an effort to figure out ways to push back against this dominant paradigm.

There have been many critiques of the muffling compliancy of the "what works" agenda over the years (e.g., Berliner \& Biddle, 1995; Cochran-Smith \& Lytle, 2006; Glass, 1987, 2008; Imig \& Imig, 2006; Labaree, 2000, 2010; Noddings, 1992; Shulman, 1998/2004; Stedman, 2010, 2011). The reduction of professional action to purported causes and effects only, oversimplifies the policy and practice discourses concerning education (Biesta, 2007). Alongside other education researchers (e.g., Cochran-Smith \& Lytle, 2006; Hargreaves \& Shirley, 2009), Biesta (2007) explains that a reason politicians (and many other stakeholders) worldwide are so enamored with "what works" is the seduction of promised quick educational fixes translated into concrete means or strategies with measureable outcomes. But politicians and many other education stakeholders are not teachers. Though not necessarily fully sure about where to go or how to proceed, the orientation of incoming CPED practitioners matches well with our Ed.D programmatic coursework to build a language that confronts the silver-bullet fallacy, arguing instead for a central role for enlarging and deepening practitioner knowledge.

$\mathrm{Au}$ (2010) has provocatively outlined the orientation of the dominant practitionerdismissing paradigm in three (unsettling) "lessons learned": (1) Teachers are not competent; (2) Diversity is bad; and (3) Local conditions are unimportant. Confronting how these assumptions impact our Ed.D students' daily lives as educators is indeed 
unsettling. Collectively interrogating what is unsettled and why, surfaces specifics about how the "what works" education agenda unproductively stifles particular perspectives and disregards educator expertise. Yet, our stance cannot be just to lament the status quo. Given the practitioners' continuing work as practitioners (and their investment in that identity), they cannot easily walk away (nor do they or we want them to). Instead, the idea is to persevere in the face of this dominant understanding and to push back against it. This is not easy work, which makes the solidarity of our cohort design additionally important.

Still, the impoverished account of practitioner knowledge resonates with and weighs heavily on our Ed.D students as their programs of study unfold. Another third cohort student compared professional development initiatives at two schools where he worked as follows:

[T]here is a part of me that felt like an in service allowed somebody to say they were doing their job...the administrator... hired some expert to come in and "teach" us. This happened at night during study hall (7:30 - 9:30) in a room with far too comfortable chairs when we all had other things to be doing. The person would get up and talk about "power words" or some such thing and give us handouts. After it was over we were on our own. Never heard about it again. It was very hard to be anything other than annoyed by these, and the odd part is I feel the head of school knew we were unhappy to participate.

Describing his current public position, he acknowledges that the conditions were better:

At [my current school] there is more thought put into in service. A full day is given to the in service, and it is led by colleagues,... revisited 4 times during the year. I feel like there is more practical information given...But there is no monitored follow up regarding implementation.

Yet, the last line still troubles both its author (our CPED student) and us. In that line there is an uncomfortable echo of Au's (2010) worry that teachers are not competent or reliable to implement better practices on their own. The paradox that we think our student is trying to articulate here is his discomfort with a compliance mentality alongside his concurrent worry that something is lost or opportunities and efficacy are missed if compliance or enactment is not expected. Responses by more classmates in the same discussion chain reveal that they too struggle with the same tensions or contradictions. 
Most of the research literature on teacher professional development does not consider this vexation, this practitioner restlessness of agreeing with some of what they are subjected to, but disagreeing with other parts and trying to figure out what a better "third way" might be. Instead, the professional literature is replete with depictions of professional development initiatives focused on "evidence-based practices" and concerned with pre-determined learning outcomes. In these accounts teachers are "good" if they heed the professional advice and bad if they do not. Yet, as the practitioners just quoted reveal, actual professional development delivered in actual settings is not so neat and clean. The dominant literature then, like the dominant practices it supports, is impoverished in that it is missing the perspectives of restless committed teachers.

Our CPED students' practice is not without echo in the research literature. With our mediation, Ed.D cohort students join the larger conversation through the research literature (or that portion of it not entangled with the dominant paradigm), challenging why teachers are provided with curricular materials as if they are incapable of making educational decisions, and reconsidering why providing measurable results that fit fixed ends is too often inadequate (Cochran-Smith \& Lytle, 2001; Darling-Hammond, 1996; Day, 2000, 2004; Delpit, 2000; Dunne, 2005; Easton, 2008; Fullan, 1999; Hargreaves, 2002; Loughran, 2010; Noddings, 1996; Olson \& Craig, 2001; Richardson, 2003; Trachtman, 2007). Kemmis and Smith's (2008) characterization of de-professionalization practices that endanger practitioner knowledge finds accordance with Ed.D cohort students as they grapple with ways to exercise professional judgments within particular teaching/ learning situations. They are increasingly aware of how the disregard for professional judgments devalues their expertise and depersonalizes teaching practices (Kincheloe, Slattery, \& Steinberg, 2000). Ed.D students are provoked by how teachers have been silenced and how curricular policies and practices assume a disembodied operating mode. Individual and collective voice is amplified across Ed.D. cohort students, gaining momentum as our CPED program pulls in the opposite direction.

Coursework deliberately fostering possibilities for seeing, analyzing, and acting on the particular complexities of classrooms illuminates the potentiality of self and other(s) within curricular situations. The empowerment of educators encountering, negotiating, and articulating the complexities of classrooms alongside other educators is concretely experienced as practitioner knowledge is developed, nurtured, and recognized/ celebrated among fellow educators. We find that it is within these programmatic spaces for questioning, resisting, adapting, and changing, that concrete practice enables educators to gain language to confidently speak, advocating for learners and learning in their own settings, communities, and beyond. 


\section{Cultivating Educators' Sensibilities}

Increasingly obvious to CPED faculty and cohort students is that curricular enactment within all educative settings becomes mere rote activity without intentionality and ongoing critical reflection on one's practices. As Freire insisted (Horton \& Freire, 1990), theory and practice ought not be separated. The theorizing voices cultivated across CPED cohort students begins with what they know about their own students, subject matter, and contexts. It is the intersections of students, subject matter, and contexts that forms and informs educators' curricular enactment. Investing in educators' sensibilities to see and act accordingly, characterizes research as a habit for all educators, not a special province to be divorced from practice or practitioners. As such, research is not reduced to a particular method, nor focused on technical procedures, nor conducted by a few for consumption by many. Rather, research is local, attentive to context with method determined through the particularities of research questions and settings, and doubly intended to flesh out theory and refine practice.

The sensibilities needed for embracing the search within research are grounded in perception. Dewey's (1934) distinction between seeing and recognition reveals the active and receptive nature of the search that perceiving entails, rather than the labeling and categorization at which recognition tends to stop. The active nature of perceiving is intentionally fostered in CPED students as they identify problems of practice derived from their own educative situations. These problems of practice, which are constantly honed and refined, then become entries into continued inquiry. Encouraged to see their problems of practice from multiple perspectives, unpacking the complexities encountered over and over again, these problems morph into searches for ways that honor and build upon the complexities of educational settings, rather than ignoring them. Cultivating this multisensory awareness takes much time and persistence. Ed.D. students find themselves moving away from the temptations of recognition strategies (that claim to eliminate or fix problems, but rarely do) towards attending to the contributing relations undergirding these problems as resources for inquiry not seen before (Heaton \& Swidler, 2012). The following example (written with overt tribute to Dewey's [1929] pedagogical creed) illuminates the growing awareness by our Ed.D students. It was written as part of a comprehensive exam response after five semesters in the program:

Education is dynamic, diverse, personal and communal, and like life, does not have to be lived one way in order to bear fruit. Too often we pay lip service to the idea of education as living, our school's mission statements profess to be "preparing life-long learners." But in claiming to "prepare" life-long learners, we deny the reality that students are already such learners...Education is not preparation, 
it is not training, it is the cultivation of what already is, it is the tending of a life that is already becoming... In the increasingly standardized, top-down, policy driven world of public education today, I feel that we are losing the sense of education as living. Orienting education towards predetermined and defined goals and already imagined future lives is dangerous; a focus on the products of education rather than its processes makes us myopic - we focus only what is measurable, what is easily perceived as an outcome. Even the word 'outcome' suggests a finality, the end of a process, something which is whole, whose parts can be seen. In many cases, the fruits of education are not ripe at the end of a lesson, a school year or upon graduation. An obsession with products leads us to restrict our processes, the multiple ways that education can be carried out, ways that it can be lived, experienced and shared. The process of education, like life itself, and the individual lives of the teachers and students who take part in it, they are not one thing, they are not done one way, and they do not produce one result...

Examples like this reveal how the active nature of perceiving entails CPED students' commitments to their students' learning experiences, following the unfolding relational complexities as productive for all involved. But, the receptive nature of perceiving is also confronted as the attention required of educators to follow these ensuing interactions insists upon a willingness to fully attend with an openness to hear, see, and feel in ways that allow for connections to form that illuminate the problems of practice.

As we document the development of our Ed.D. students' problems of practice, it seems that involving educators in practicing the needed receptivity creates room to precipitate suggestions. These receptive modes invite educators to make room for deliberation. Flexibility and patience are called upon here, as educators reconsider their aims and habits, sometimes painfully. Intuition also finds room to be negotiated. Educators reveal previous experiences and reexamine the patterns, structures, and conditions of those experiences. Those then become the genesis of new pursuits. Room for anticipation is also found. Educators' problems of practice involve them in a search for continuity as the recursive cycles entailed in the refinement and addressing of their problems of practice continually anticipate possible connections en route. This anticipatory ground makes room for new ideas interdependent with willingness to navigate conflict, discomforts, and uncertainty, alongside the creative and invigorating energy of new terrain. Enlarged realizations are instilled, suggested through these receptive modes of deliberation, intuition, anticipation, and the emergence of new ideas. 
The problems of practice revisited throughout the program of study offer productive pauses, allowing room to form suggestions and to act on them. It is this active and receptive process of inquiry that expands the range of fruitful possibilities for future action and future decisions that the problems of practice increasingly embrace. The primary avenue that avails, positions educators with the sensitivities to approach problems of practice not as matters to eliminate, but as forming the matters integral to the ongoing search for better learning and teaching and the associated beliefs and habits that accompany these defining tasks within a culture of learning.

\section{Cultivating Educators' Capacities}

Problems of practice for our Ed.D. students are not resolved so much as refined or transformed into new conditions that implicate new problems. This does not imply that attention to problems of practice does not position practitioners to be more efficacious with their practice. Rather, from the habit of inquiry that is part and parcel of attending to a problem of practice, each step forward sheds new insights into the possibilities and problems not seen before. The Ed.D. students are positioned to seize the opportunities and challenges of continually reformulating their problems of practice as all coursework embeds practices that productively complicate students' theory/practice relations. Thus, throughout the program as a whole, Ed.D. students are asked to examine education, not only as it exists, but also as a phenomenon involving deeply ethical responsibilities and judgments that underlie educational theories and practices as manifested in classrooms, research, and policy. In our CPED program, education as concerned with ethical spaces becomes difficult to dismiss, as coursework continually opens into ethical considerations at play through embracing the given multiplicities all participants bring to bear. Drawing across grade levels, disciplines, and settings, the conversations generated through coursework position all involved to learn with and through others. Thus, the roles of differences as catalysts in coming to know self and other(s) become empowering capacities that shape the evolution of our Ed.D. practitioners.

Programmatic practices emulate the enactive nature of practitioner knowledge that invests in the formative nature of professional knowledge. In turn, our Ed.D. graduates invest in the formative nature of learning, enacted within their own educative settings. As Chan (2012), one of our CPED faculty colleagues has explained, throughout the program our students find themselves "shifting [their] sense of professional identity" (p. 185) both as teachers and as researchers. Negotiating this dual identity is often difficult (Wilhelm, 2008), always complex, and likely ultimately enriching for the graduate, for his/her students, and for the profession. The Ed.D. positions all involved 
to reconsider and renegotiate their teaching identities, creating the necessary spaces where educators' practices can be developed and nurtured, problems of practice can be enacted as ongoing challenges and opportunities, and greater agency for teachers can be claimed, thereby furthering student learning.

As our Ed.D students graduate, we take pride in the professional practitioners we see reinvesting and revitalizing educative practices as they assume new and enhanced roles within their communities because of capacities gained related to our program outcomes. A student nearing graduation explains:

The classes I took as a CPED cohort member have helped me immeasurably in my role as an educational practitioner. Now, I'm able to speak with confidence about the issues facing teachers and advocate for practices I believe beneficial to teaching. My beliefs are backed by the research we read, discussed, and wrote about in our CPED classes. As a doctoral candidate, I know I will continue to keep up with current research long after I complete my dissertation.

In brief, we see their successful contestation of the paradigmatic understandings that worried $\mathrm{Au}$ (2010). It is the concrete practice with capacities gained through confronting, articulating, enacting, and celebrating practitioner knowledge in our Ed.D. program that creates a community of learning professionals invested in enlarging understandings of education that will extend beyond local communities over time. Our Ed.D. graduates express well-honed strengths of conviction regarding their personal teaching identities and educators' agentive importance within learning contexts that suggest long-term professional connections. It is the fruits of these capacities that we see as very much sustaining and nurturing educators' professional knowledge over the long term.

\section{From Inchoate Restlessness to Practitioner Leader}

The patterns cultivating practitioner voice, sensibilities, and capacities as reflected within the experiential in situ data suggest that our CPED program has been understood by participants (students and faculty) as a refuge of sorts, a space where "practitioner knowledge counts." In that sense-participants think it is what it purports to be-a program different from and counter to some other currents that attempt to reductively define and impose external characterizations of practitioner knowledge. It is a co-created space offering sustenance practitioners are seeking, and in doing so, it models professional development that cultivates individual/collective practitioner knowledge always in the making. 
As a multi-university initiative that attempts to redefine graduate teacher education by changing both the internal purposes of university Ed.D. preparation and the external way the Ed.D. is understood (as a degree indicating expertise in practice), CPED is an important initiative, directly involving dozens of institutions of higher education with implications for many more (Macintyre Latta \& Wunder, 2012). An account of our promising (so far) implementation at our campus should be relevant elsewhere as it illustrates a viable way to cultivate practitioner knowledge with important implications for embedded professional development. It also serves as a reminder to the field writ large that local, context-responsive actions by reflective, skilled practitioners are key ways that educational knowledge manifests itself as inquiry that values and invests in teachers' voices, sensibilities, and capacities.

We see much evidence that professional development characterized as cultivating educators' voices, sensibilities, and capacities to invest in learners and learning, grounded within the particularities of their own educative contexts, incites professional agency. Groundwater-Smith and Campbell (2010) point out that such agency rests in part "upon the nature of the relationship between teachers as practitioner researchers and those who may support them" (p. 201). It is the nature of this relationship between participating educators as practitioner researchers and participating faculty that the CPED program foregrounds, positioning all involved to negotiate this relationship in an ongoing, respectful manner. The manifesting relationships invest in professional knowledge that is socially constructed through the purposeful interchange of multiperspectival theories with concrete educative practices and policies. As faculty, our professional knowledge has enlarged and deepened alongside our CPED students' professional knowledge. We bring knowledge to the table, but that knowledge is enhanced, challenged, and deepened as we reference it dialogically with the CPED students. It needs to not only make sense in the abstract, but also to be relevant to the restless purposefulness that these expert practitioners operating in particular contexts are endeavoring to hone.

Formative professional knowledge is increasingly documented worldwide as holding the needed agency for educative practices and policies to productively connect inquiry with professional learning in education (Groundwater-Smith \& Campbell, 2010). The productivity our CPED program chronicles is conveyed through educators' growing voices, sensibilities, and capacities to articulate, see, and act to further learning, given the complexities and diversities encountered in varied educative settings. It is the relational investment in practitioner knowledge that does not separate practitioners from researchers that we see as foundational to the professional development that enables CPED students and faculty to advocate for educative practices that build and 
sustain learning contexts that position all involved as inquirers. Or, in the words of a CPED student:

[I]n claiming to 'prepare' life-long learners, we deny the reality that students are already such learners, we pretend that the joy of learning is in the future, we prepare them to exercise this learning later... Because you'll need to know it when you grow up, get to junior high, go to college, etc. is a common and unfortunate rationale for much of the education we provide in public schools...

Our CPED program embodies the needed professional agency to inquire, providing much-needed sustenance for professional learning that we experience to be empowering for all involved. It offers a pathway to address the too common denial of teacher voice, sensibilities, and capacities within educative practices and policies that typify much of what constitutes professional development for educators worldwide. And, it is a pathway that we now see our Ed.D. graduates extending further as they assume leadership roles in their educative settings, continuing to invest in the development of their own practitioner knowledge while creating the circumstances to invest in the development of their colleagues' professional knowledge. The possibilities impacting all stakeholders-from learners to teachers to administrators to policy makers to parents-hold the potentials that invigorate continued investment in our Ed.D. Program.

\section{References}

Au, W. (2010). The idiocy of policy: The antidemocratic curriculum of high-stakes testing. Critical Education, 1(1). Retrieved from http://m1.cust.educ.ubc.ca/journal/v1n1

Bannan-Ritland, B. (2003). The role of design in research: The integrative learning design framework. Educational Researcher, 32(1), $21-24$.

Berliner, D. C., \& Biddle, B. J. (1995). The manufactured crisis: Myths, fraud, and the attack on America's public schools. New York: AddisonWesley. (Republished by Harper Collins).
Biesta, G. J. J. (2007). Why "what works" won't work. Evidence-based practice and the democratic deficit of educational research. Educational Theory, 57(1), 1-22.

Borko, H. (2004). Professional development and teacher learning: Mapping the terrain. Educational Researcher, 33(8), 3-15.

Carnegie Project on the Education Doctorate (CPED). (n.d.). The Carnegie Foundation for the Advancement of Teaching. Retrieved from http://www.carnegiefoundation.org/ education-doctorate

Carr, D. (2000). Professionalism and ethics in teaching. London: Routledge. 
Chan, E. (2012). From teacher to researcher, researcher to teacher: Examining teachers' experiences of conducting research in their education settings. In M. Macintyre Latta \& S. Wunder (Eds.). Placing practitioner knowledge at the center of teacher education; Rethinking the policies and practices of the Education Doctorate. (pp. 179-198). Charlotte, NC: Information Age Publishing.

Cobb, P., Confrey, J., diSessa, A., Lehrer, R., \& Schauble, L. (2003). Design experiments in educational research. Educational Researcher, 32(1), 9-13.

Cochran-Smith, M. (2006). Policy, practice, \& politics in teacher education. Thousand Oakes, CA: Corwin.

Cochran-Smith, M., \& Lytle, S. L. (2001). Beyond certainty: Taking an inquiry stance on practice. In A. Lieberman \& J. L. Miller (Eds.), Teachers caught in the action: Professional development that matters. New York: Teachers College Press.

Cochran-Smith, M., \& Lytle, S. L. (2006). Troubling images of teaching in No Child Left Behind. Harvard Educational Review, 76(4), 668-697.

Cochran-Smith, M., \& Lytle, S. L. (2009). Inquiry as stance: Practitioner research for the next generation. New York: Teachers College Press.

Darling-Hammond, L. (1996). What matters most: A competent teacher for every child. Phi Delta Kappan, 76(8), 597-604.

Day, C. (2000). Stories of change and professional development: The costs of commitment. In C. Day, A. Fernandez, T. Hauge, \& J. Moller (Eds.), The life and work of teachers: International perspectives in changing times (pp. 109-129). London: Falmer Press.

Day, C. (2004). A passion for teaching. New York: Routledge.

Delpit, L. (2000). The silenced dialogue: Power and pedagogy in the education of other peoples' children. Harvard Educational Review, 58(3), 280-298.

Design-Based Research Collective. (2003). Design-based research: An emerging paradigm for educational inquiry. Educational Researcher, 32(1), 5-8.
Dewey, J. (1929). My pedagogic creed. Journal of the National Education Association, 18(9), 291-295.

Dewey, J. (1934). Art as experience. New York: Penguin Press.

Dunne, J. (2005). An intricate fabric: Understanding the rationality of practice. Pedagogy, Culture and Society, 13(3), 367-389.

Easton, L. B. (2008). From professional development to professional learning. Phi Delta Kappan, 89(10), 755-759.

Edelson, D. C. (2002). Design research: What we learn when we engage in design. Journal of the Learning Sciences, 11(1), 105-121.

Eisner, E.W. (1992). Educational reform and the ecology of schooling. Teachers College Record, 93(4), 610-627.

Fullan, M. G. (1999). Change forces: The sequel. London: Falmer Press.

Glass, G. (1987). What works: Politics and research. Educational Researcher, 14(3), 5-10.

Glass, G. (2008). Fertilizers, pills, and magnetic strips: The fate of public education in America. Charlotte, NC: Information Age.

Groundwater-Smith, S., \& Mockler, N. (2009). Teacher professional learning in an age of compliance: Mind the gap. London: Springer.

Groundwater-Smith, S., \& Campbell, A. (2010). Joining the dots: Connecting inquiry and professional learning. In A. Campbell \& S. Groundwater-Smith (Eds.), Connecting inquiry and professional learning in education: International perspectives and practical solutions (pp. 200-206). New York: Routledge.

Hamann, E. T. (2005). Systemic High School Reform in Two States: The Serendipity of State-Level Action. High School Journal, 89(Oct./Nov.): 1-17. Retrieved from http:// muse.jhu.edu/journals/high_school_journal/v089/89.1hamann.pdf

Hargreaves, A. (2002). Teaching in a box: Emotional geographies of teaching. In C. Sugrue \& C. Day (Eds.), Developing teachers and teaching practice: International research perspectives (pp. 3-25). London: RoutledgeFalmer. 
Hargreaves, A., \& Shirley, D. (2009). The persistence of presentism. Teachers College Record, 111(11), 2505-2534. Retrieved from http:// www.tcrecord.org ID Number: 15438

Heaton, R.M., \& Swidler, S.A. (2012). Learning to see inquiry as a resource for practice. In $\mathrm{M}$. Macintyre Latta \& S. Wunder (Eds.). Placing practitioner knowledge at the center of teacher education; Rethinking the policies and practices of the Education Doctorate. (pp. 89-104). Charlotte, NC: Information Age Publishing.

Horton, M., \& Freire, P. (1990). We make the road by walking: Conversation and education and social change. B. Bell, J. Gaventa, \& J. Peters (Eds.). Philadelphia: Temple University Press.

Imig, D.G., \& Imig, S.R. (2006). The teacher effectiveness movement: How 80 years of essentialist control have shaped the teacher education profession. Journal of Teacher Education, 57(2), 167-180.

Kemmis, S., \& Smith, T. (2008). Praxis and praxis development. In S. Kemmis \& S. T. (Eds.), Enabling praxis: Challenges for education (pp. 3-14). Rotterdam, The Netherlands: Sense Publishers.

Kincheloe, J., Slattery, P., \& Steinberg, S. (2000). Contextualizing teaching: Introduction to education and educational foundations. Reading, MA: Longman.

Labaree, D.F. (2000). On the nature of teaching and teacher education: Difficult practices that look easy. Journal of Teacher Education, 51(3), 228-233.

Labaree, D.F. (2010). Someone has to fail: The zerosum game of public schooling. Cambridge, MA: Harvard University Press.

Lieberman, A., \& Pointer-Mace, D. H. (2008). Teacher learning: The key to educational reform. Journal of Teacher Education, 59(3), 226-234.

Loughran, J. (2010). What expert teachers do: Enhancing professional knowledge for classroom practice. New York: Routledge.

Macintyre Latta, M., \& Field, J.C. (2005). The flight from experience to representation: Seeing relational complexity in teacher education. Teaching and Teacher Education, An International Journal of Research and Studies, 21, 649-660.
Macintyre Latta, M., \& Wunder, S. (Eds.) (2012). Placing practitioner knowledge at the center of teacher education--Rethinking the policies and practices of the education doctorate. In E. Hamann \& R. Hopson (Eds.), Education Policy in Practice: Critical Cultural Studies Series. Charlotte, NC: Information Age Publishing.

McGowan, T.M., \& Pedersen, J.E. (2012). No longer "PhD-lite": Establishing a professional practice doctorate of substance. In M. Macintyre Latta \& S. Wunder (Eds.). Placing practitioner knowledge at the center of teacher education; Rethinking the policies and practices of the Education Doctorate (pp. 233-248). Charlotte, NC: Information Age Publishing.

Nespor, J. (2006). Finding patterns with field notes. In Green, J., Camilli, G., \& Elmore, P. (Eds.), Complementary methods for research in education (pp. 587-598). Washington, DC: American Educational Research Association.

Noddings, N. (1992). The challenge to care in schools: An alternative approach to education. New York: Teachers College Press.

Noddings, N. (1996). Stories and affect in teacher education. Journal of Education, 26(3), 435-447.

Olson, M. R., \& Craig, C. (2001). Opportunities and challenges in the development of teachers' knowledge: The development of narrative authority through knowledge commmunities. Teaching and Teacher Education, 17(6), 667-684.

Proefriedt, W. (2008). High expectations: The cultural roots of standards reform in American education. New York: Teachers College Press.

Ravitch, D. (2010). The death and life of the great American school system: How testing and choice are undermining education. New York: Basic Books.

Ravitch, D. (2013). Reign of error. New York. Knopf.

Richardson, V. (2003). The dilemmas of professional development. Phi Delta Kappan, 84(5), 401-409.

Shulman, L. S. (1998/2004). Theory, practice, and the education of professionals. In L. S. Shulman. The wisdom of practice: Essays on teaching, learning, and learning to teach (pp. 523-544). San Francisco: Jossey-Bass. 
Shulman, L. S. (2004) The wisdom of practice: Essays on teaching, learning, and learning to teach. San Francisco: Jossey-Bass.

Shulman, L. S., Golde, C. M., Conklin Bueschel, A., \& Garabedian, K. J. (2006). Reclaiming education's doctorates: A critique and a proposal. Educational Researcher, 35(3), 25-32.

Sidorkin, A.M. (2002). Learning relations: Impure education, deschooled schools, and dialogue with evil. New York: Peter Lang.

Stake, R. (2005). Qualitative case studies. In N. Denzin and Y. Lincoln. The Sage handbook of qualitative research, Third Edition. (pp. 443466). Thousand Oaks, CA: Sage.

Stedman, L. C. (2010). How well does the standards movement measure up? An analysis of achievement trends and student learning, changes in curriculum and school culture, and the impact of No Child Left Behind. Critical Education, 1(10). Retrieved from http://ml.cust.educ.ubc.ca/journal/index. $\mathrm{php/criticaled/issue/view133}$

Stedman, L. C. (2011). Why the standards movement failed: An educational and political diagnosis of its failure and the implications for school reform. Critical Education, 2(1), Retrieved from http://m1.cust.educ.ubc.ca/ journal/index.php/criticaled
Townsend, T., \& Bates, R. (Eds.). (2007). Handbook of teacher education: Globalization, standards, and professionalism in times of change. Dordrecht, The Netherlands: Springer.

Trachtman, R. (2007). Inquiry and accountability in professional development schools. Journal of Educational Research, 100(4), 197-203.

van den Akker, J. (1999). Principles and methods of development research. In J. van den Akker, R. Branch, K. Gustafson, N. Nieveen, \& T. Plomp (Eds.), Design approaches and tools in education and training (pp. 1-15). Dordrecht: Kluwer Academic Publishers.

Wang, F., \& Hannafin, M. J. (2005). Design-based research and technology-enhanced learning environments. Educational Technology Research and Development, 53(4), 5-23.

Wilhelm, J.D. (2008). You gotta BE the book (2nd ed.). New York: Teachers College Press.

Yin, R. (2003). Case study research: Design and methods. Thousand Oaks, CA: Sage. 


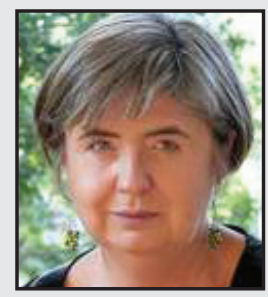

Margaret Macintyre Latta is a former Graduate Chair in Teaching, Learning, \& Teacher Education and Professor at the University of Nebraska-Lincoln. She is currently a Professor and Director of the Centre for Mindful Engagement and Graduate Programs in the Faculty of Education at the University of British Columbia Okanagan. Her books, Curricular Conversations: Play is the (Missing) Thing (2013), Teaching the Arts to Engage ELLs (2011), and The Possibilities of Play in the Classroom: On the Power of Aesthetic Experience in Teaching, Learning, and Researching (2001), document and reveal the aesthetics of human understanding, understood as attention to process, as integral within learning of all kinds.

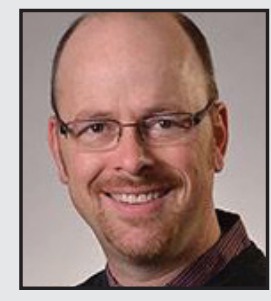

Edmund T. Hamann is a Professor in the University of Nebraska-Lincoln's (UNL) Department of Teaching, Learning \& Teacher Education. There, in addition to being an anthropologist of education and expert on school responses to transnationally mobile children and families, he coordinates his department's participation in the Carnegie Program on the Educational Doctorate (CPED). Prior to coming to UNL in 2005, he was a research and evaluation specialist at the Northeast and Islands Regional Educational Laboratory that was then at Brown University.

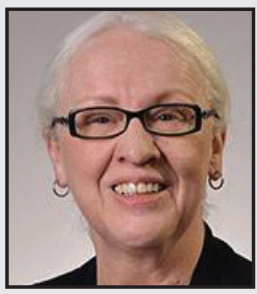

Susan A. Wunder is Associate Professor Emerita in the Department of Teaching, Learning and Teacher Education at the University of Nebraska-Lincoln. She was the Interim Department Chair from 2013 to 2015 and Coordinator for the Carnegie Project on the Education Doctorate program in her department from 2009 to 2015. 